\title{
The influence of HK2 blood group antigen on human $B$ cell activation for ABOi-KT conditions
}

\author{
Jingsong $\mathrm{CaO}^{1,2+} \mathbb{D}$, Luogen $\mathrm{Liu}^{2 \dagger}$, Yunsheng Zhang ${ }^{2}$, Jianhua Xiao ${ }^{1,2^{*}}$ and Yi Wang ${ }^{2,3^{*}}$
}

\begin{abstract}
Background: It is well known that $\mathrm{ABO}$ blood group system incompatible kidney transplantation (ABOi-KT) is an effective strategy for end-stage renal disease. The main barrier for ABOi-KT is how to keep host B cell activation and blood group antibody titer in low levels. Moreover, the mechanism of B cell activation induced by blood group antigen was unclear in ABOi-KT.

Results: In this study, HK2 cells were identified to express blood group B antigen when cocultured with lymphocytes of blood group A. Optical microscope observation demonstrated that HK2 cells in coculture group gradually decreased. Furthermore, flow cytometer assay identified that T cell phenotypes $\left(\mathrm{CD}^{+}, \mathrm{CD}^{+} \mathrm{CD}^{+}\right.$and $\mathrm{CD}^{+} \mathrm{CD}^{+}$) had no significant change and B cell phenotypes $\left(\mathrm{CD} 19^{+}\right.$and $\left.\mathrm{CD} 138^{+}\right)$were all significantly enhanced (3.07 and 3.02 folds) at day 4 . In addition, immunoturbidimetry analysis demonstrated that blood group B antibody was significantly increased to 2.35 fold at day 4, IgG was significantly increased to 3.60 and 2.81 folds at days 4 and 8 respectively, while IgM had no significant change at the measured time points.

Conclusions: Taken together, B cells were activated and secreted blood group B antibody after treatment with HK2 expressing blood group $B$ antigen. The results of this study maybe useful for further determination of the mechanism of $B$ cell activation after $A B O$ incompatible kidney endothelial cells stimulation.
\end{abstract}

Keywords: Blood group B antigen, Blood group B antibody, HK2, B cells activation, ABOi-KT

\section{Background}

$\mathrm{ABOi}-\mathrm{KT}$ is an effective replacement therapy for endstage kidney disease [1-3], in which the key for graft survival is to eliminate the host blood group antibodies prestored in peripheral blood of recipients $[4,5]$. However, the allograft in part of ABOi-KT recipients survived without rejection when the blood group antibody titer was gradually increased to the preoperative level [6].

Some researchers considered the allograft survival was related to immune tolerance mediated by antibodies [7,

\footnotetext{
* Correspondence: jhxiao223@163.com; wayne0108@126.com

${ }^{\dagger}$ Equal contributors

${ }^{1}$ Institute of Pathogenic Biology, Medical College, Hunan Provincial Key Laboratory for Special Pathogens Prevention and Control; Hunan Province Cooperative Innovation Center for Molecular Target New Drug Study, University of South China, Hengyang, Hunan 421001, China

${ }^{2}$ Clinical research center, Institute of Pathogenic Biology, Medical College, The Second Affiliated Hospital, University of South China, Hengyang, Hunan 421001, China

Full list of author information is available at the end of the article
}

8]. Urschel et al. showed CD21-expressing B cells were related to $\mathrm{ABO}$ tolerance [9]. Chesneau et al. reported a unique $B$ cell in vitro differentiation profile that played an important role in tolerant kidney transplant patients [10], especially the isotype of immunoglobulin (Ig) on the surface of B cells switch from IgM to IgG $[11,12]$. Methot et al. [13] noted that B cell differentiation resulted in antibody diversification, which impacted the antibodies activity for binding to Fc receptors and activation of the complement system [8]. However, the mechanism of B cells activation in ABOi-KT was unclear.

In this study, HK2 cells were identified to express blood group B antigen. After coculture with lymphocytes isolated from blood group A health donors, the HK2 cells were observed by optical microscopy. Of these, the lymphocytes phenotype, such as $\mathrm{CD}^{+}, \mathrm{CD}^{+} \mathrm{CD}^{+}, \mathrm{CD} 3$ ${ }^{+} \mathrm{CD} 88^{+}, \mathrm{CD} 19^{+}$and $\mathrm{CD} 138^{+}$, were analyzed by flow cytometry. Furthermore, the blood group B antibody, IgG and IgM were detected by immunoturbidimetry assay. 
These results will be beneficial for further exploration of the mechanism of $\mathrm{B}$ cells activation after $\mathrm{ABO}$ incompatible kidney endothelial cells stimulation.

\section{Methods}

HK2 cell line was purchased from the Advanced Research Center of Central South University. The peripheral blood was donated from volunteers after informed consent, and subsequently approved by the Animal Welfare and Research Ethics Committee of the Institute of University of South China.

The specificity glycosyl of blood group B antigen was synthesized and coupled to keyhole limpet hemocyanin (KLH-B) at Alberta Innovates Technology Futures. The KLH-B was dissolved in phosphate buffer solution (PBS, $0.01 \mathrm{~mol} / \mathrm{L}, \mathrm{pH} 7.4$ ) to $0.001 \mathrm{mg} / \mathrm{ml}$.

\section{Cell culture}

Lymphocytes were separated from blood group A donors and cultured as Cao et al. [14] reported with some modification. Peripheral blood at $2 \mathrm{ml}$ was mixed with $0.9 \%$ physiological saline $(V: V=1: 1)$ for ficoll gradient separation (LymphoPrep). After centrifugation at 1800 revolutions/min for $20 \mathrm{~min}$, the lymphocytes layer was collected and rinsed 2 times with $0.9 \%$ physiological saline at 1500 revolutions/min for $7 \mathrm{~min}$. Then the cells were resuspended with 1640 medium (Thermo Fisher Scientific) and $15 \%$ fetal calf serum (FCS, Thermo Fisher Scientific) to $2 \times 10^{6}$ cells $/ \mathrm{ml}$.

The HK2 cells in dish culture were processed by $3 \mathrm{ml}$ $0.25 \%$ trypsin (GE Healthcare Life Sciences) at room temperature for 2 minnutes, then $3 \mathrm{ml} 1640$ medium with 15\% FCS added, and centrifuged at 800 revolutions/min for $10 \mathrm{~min}$. Afterwards was rinsed 2 times with $0.9 \%$ physiological saline at 800 revolutions/min for $10 \mathrm{~min}$, the precipitate was resuspended with 1640 medium and $15 \%$ FCS to $2 \times 10^{6}$ cells $/ \mathrm{ml}$.

Then, leukocytes and HK2 cells were divided into three groups, HK2 group was added $0.5 \mathrm{ml}$ HK2 cells suspension and $0.5 \mathrm{ml} 1640$ medium with $15 \%$ FCS, PB group was added $0.5 \mathrm{ml}$ lymphocytes suspension and $0.5 \mathrm{ml} 1640$ medium with $15 \%$ FCS, coculture group was added $0.5 \mathrm{ml} \mathrm{HK} 2$ cells suspension and $0.5 \mathrm{ml}$ lymphocytes suspension. The three groups were all cultured in 24-well plates at $37{ }^{\circ} \mathrm{C}, 5 \% \mathrm{CO}_{2}$, and added $0.1 \mathrm{ml}$ fresh medium to every group at day 4 . The experiment was repeated for 3 times.

\section{Immunohistochemistry assay}

The process of immunohistochemistry was built as Kounelis [15] reported with some modification. HK2 cells were cultured with 1640 medium and 15\% FCS at $37{ }^{\circ} \mathrm{C}, 5 \% \mathrm{CO}_{2}$. After rinsed with $\mathrm{PBS}(0.01 \mathrm{~mol} / \mathrm{L}$,
$\mathrm{pH}$ 7.2) for 2 times, the carry sheet glasses of HK2 cells were incubated with FCS at $37{ }^{\circ} \mathrm{C}$ for $20 \mathrm{~min}$. Then the carry sheet glasses were divided into three groups, one group was incubated with $1 \mathrm{ml} \mathrm{PBS}$ at $37^{\circ} \mathrm{C}$ for $1 \mathrm{~h}$, the other two groups were respectively incubated with mouse monoclonal to anti-blood group A antibody (1: 100, Albanian Broadband Communication) and mouse monoclonal to anti-blood group B antibody (1: 100, Albanian Broadband Communication) at $37^{\circ} \mathrm{C}$ for $1 \mathrm{~h}$. After rinsed 3 times with PBS for 2 min, the three groups were all incubated with goat anti-mouse IgM-HRP (1: 500, ThermoFisher Scientific) at $37{ }^{\circ} \mathrm{C}$ for $20 \mathrm{~min}$, followed rinsed 3 times with PBS for 2 min. Finally, the carry sheet glasses were rinsed 3 times with PBS for 2 min and analyzed with DAB Kit (BOSTER) detection method. The experiment was repeated for 3 times.

\section{Optical microscope observation}

At days 2, 4, 8, the lymphocytes were collected for further research. HK2 cells were observed by optical microscopy after two PBS rinses. The experiment was repeated for 3 times.

\section{Flow cytometer assay}

At days 2, 4, 8, the lymphocytes suspension were collected by concentrated at 1000 revolutions/min for $10 \mathrm{~min}$, then the precipitate was resuspended with $1 \mathrm{ml} 0.9 \%$ physiological saline, after centrifuged at 1000 revolutions/min for $10 \mathrm{~min}$, the precipitate was resuspended with $150 \mu \mathrm{l}$ $0.9 \%$ physiological saline, and divided into three groups. One group as isotype control was added FITC mouse $\operatorname{IgG} 2 \alpha(5 \mu \mathrm{l}, \mathrm{BD})$, PE mouse IgG1 $(5 \mu \mathrm{l}, \mathrm{BD})$ and PerCP-CyTM 5.5 mouse IgG1 $(1 \mu \mathrm{l}, \mathrm{BD})$, the experiment group was divided into two group and, respectively, added FITC mouse anti-human CD3 (5 $\mu \mathrm{l}, \mathrm{BD})$, PE mouse anti-human CD4 (5 $\mu \mathrm{l}, \mathrm{BD})$, PerCP-CyTM5.5 mouse anti-human CD8 $(1 \mu \mathrm{l}, \mathrm{BD})$ and FITC mouse anti-human CD19 (5 $\mu \mathrm{l}, \mathrm{BD})$, $\mathrm{PE}$ mouse anti-human CD138 (5 $\mu \mathrm{l}, \mathrm{BD})$. The three groups were all incubated at room temperature for $15 \mathrm{~min}$, then resuspended with $1 \mathrm{ml} 0.9 \%$ physiological saline and centrifuged at 1000 revolutions/min for $10 \mathrm{~min}$. Finally, the precipitate was resuspended with $0.2 \mathrm{ml} 0.9 \%$ physiological saline and prepared to analysis using $\mathrm{BD}$ FACSCanto II. The experiment was repeated for 3 times.

\section{Detection of the concentration of mouse monoclonal to anti-blood group $B$ antibody in reagent}

After polyacrylamide gel electrophoresis (PAGE, 8\% separation gel) of mouse monoclonal to anti-blood group B antibody reagent, the gel was transferred to a polyvinylidene fluoride (PVDF) membrane for 90 minnutes at $300 \mathrm{~mA}$ in transfer buffer $(0.025 \mathrm{~mol} / \mathrm{L}$ Tris, $0.1 \mathrm{~mol} / \mathrm{L}$ glycine, and $20 \%$ methanol), and the membrane was 
blocked for $1 \mathrm{~h}$ in tween tris buffer solution (TTBS, 0.05\% Tween-20, $0.02 \mathrm{~mol} / \mathrm{L}$ Tris, $0.15 \mathrm{~mol} / \mathrm{L} \mathrm{NaCl}$, $\mathrm{pH}$ 7.4) containing $5 \%$ skim milk at room temperate. After rinsed 3 times with tris buffer solution (TBS) for $5 \mathrm{~min}$, the membrane was incubated with goat antimouse IgM-HRP (1: 2000) at room temperate for $40 \mathrm{~min}$. Then the membrane was rinsed 2 times with TBS for $15 \mathrm{~min}$ and analyzed with ECL Plus (solarbio) chemiluminescence detection method.

In addition, the concentration of mouse monoclonal to anti-blood group B antibody was calculated by protein-gray value curve of bovine serum albumin (BSA). The experiment was repeated for 3 times.

\section{Immunoturbidimetry assay}

At days 2, 4, 8, the supernate was collected. Experiment group was a mixture of the supernate, buffer solution (0.01 mol/L, pH 7.4 PBS, $0.15 \mathrm{~mol} / \mathrm{L} \mathrm{NaCl}, 40 \mathrm{~g} / \mathrm{L}$ PEG-8000) and KLH-B ( $V: V: V=1: 94: 5)$. positive control group was a mixture of mouse monoclonal to anti-blood group B antibody, buffer solution and KLH-B ( $V: V: V=1$ : 94: 5). Blank group was a mixture of buffer solution and KLH-B ( $V: V=95: 5)$. All groups were incubated at room temperature for $5 \mathrm{~min}$, and then detected the absorb value at $\lambda_{340 \mathrm{~nm} \text {. }}$.

Meanwhile, The IgM and IgG in supernate were respectively analyzed by $\mathrm{N}$ Antiserum to Human IgM reagent (Siemens) and $\mathrm{N}$ Antiserum to Human IgG reagent (Siemens). The experiments were all repeated for 3 times.

\section{Results}

Identification of blood group antigen type of HK2 cells To research the change of $\mathrm{B}$ cell activation by blood group antigens of kidney endotheliocytes stimulated in vitro, the blood group antigen type of the HK2 cell line was analyzed by immunohistochemistry (Fig. 1). As for results, none of the imaged HK2 cells were stained after incubation with PBS and mouse monoclonal to anti- blood group A antibody (Fig. 1 a, b). However, the HK2 cells could specifically link with mouse monoclonal to anti-blood group B antibody (Fig. 1c).

\section{Observation of HK2 cells proliferation}

Following the results of immunohistochemistry, lymphocytes of blood group A were collected and cultured with HK2 cells. At days 2, 4, 8, HK2 cells were observed by optical microscopy (Fig. 2). Compared with PB (Fig. 2a) and HK2 groups (Fig. 2b, d), the proliferative activity of HK2 cells in coculture group was decreased and a small number of HK2 cells survived at day 8 (Fig. 2c, d).

\section{Analysis of lymphocytes phenotype}

To demonstrate the lymphocyte subtypes influencing HK2 cells proliferative activity, the $\mathrm{T}$ cells phenotype $\left(\mathrm{CD}^{+}, \mathrm{CD}^{+} \mathrm{CD}^{+}{ }^{+}\right.$and $\left.\mathrm{CD}^{+} \mathrm{CD}^{+}\right)$and $\mathrm{B}$ cells phenotype $\left(\mathrm{CD} 19^{+}\right.$and $\left.\mathrm{CD} 138^{+}\right)$were analyzed by flow cytometer. As Fig. 3 appeared, compared with PB group, $\mathrm{T}$ cell phenotypes (Fig. $3 \mathrm{a}-\mathrm{c}$ ) had no significant change, and $\mathrm{CD}_{19^{+}}$(Fig. 3d, f) B cells were significantly increased to 3.07 fold at day $4, \mathrm{CD} 138^{+}$(Fig. 3e, f) B cells were significantly increased to 3.02 and 1.36 folds at days 4 and 8 respectively.

\section{Determination of the anti-blood group B mouse monoclonal antibody concentration}

For further exploration of the variation of blood group $\mathrm{B}$ antibody secreted by B cells, the concentration of mouse monoclonal to anti-blood group B antibody in reagent was analyzed. As Fig. 4 showed, in the reagent, only the protein with a molecular weight about $181.7 \mathrm{kDa}$ was specifically combined with goat anti mouse IgM-HRP. After comparison with the standard curve of BSA (Additional file 1: Figure S1), the mouse monoclonal to anti-blood group $\mathrm{B}$ antibody concentration was identified as $0.57 \mathrm{mg} / \mathrm{ml}$.
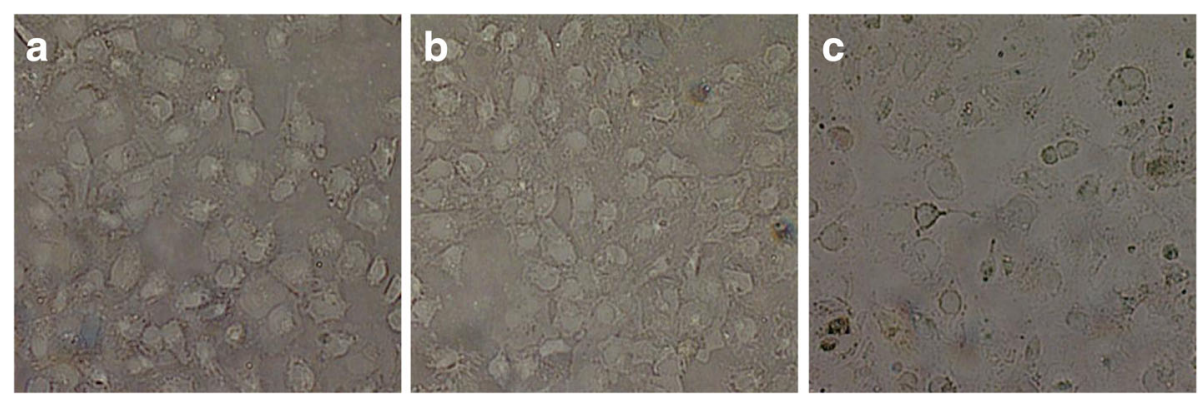

Fig. 1 Blood group antigen identified by immunohistochemistry. a PB group, b Blood group A antigen analysis, c Blood group B antigen analysis. All groups were repeated for 3 times 


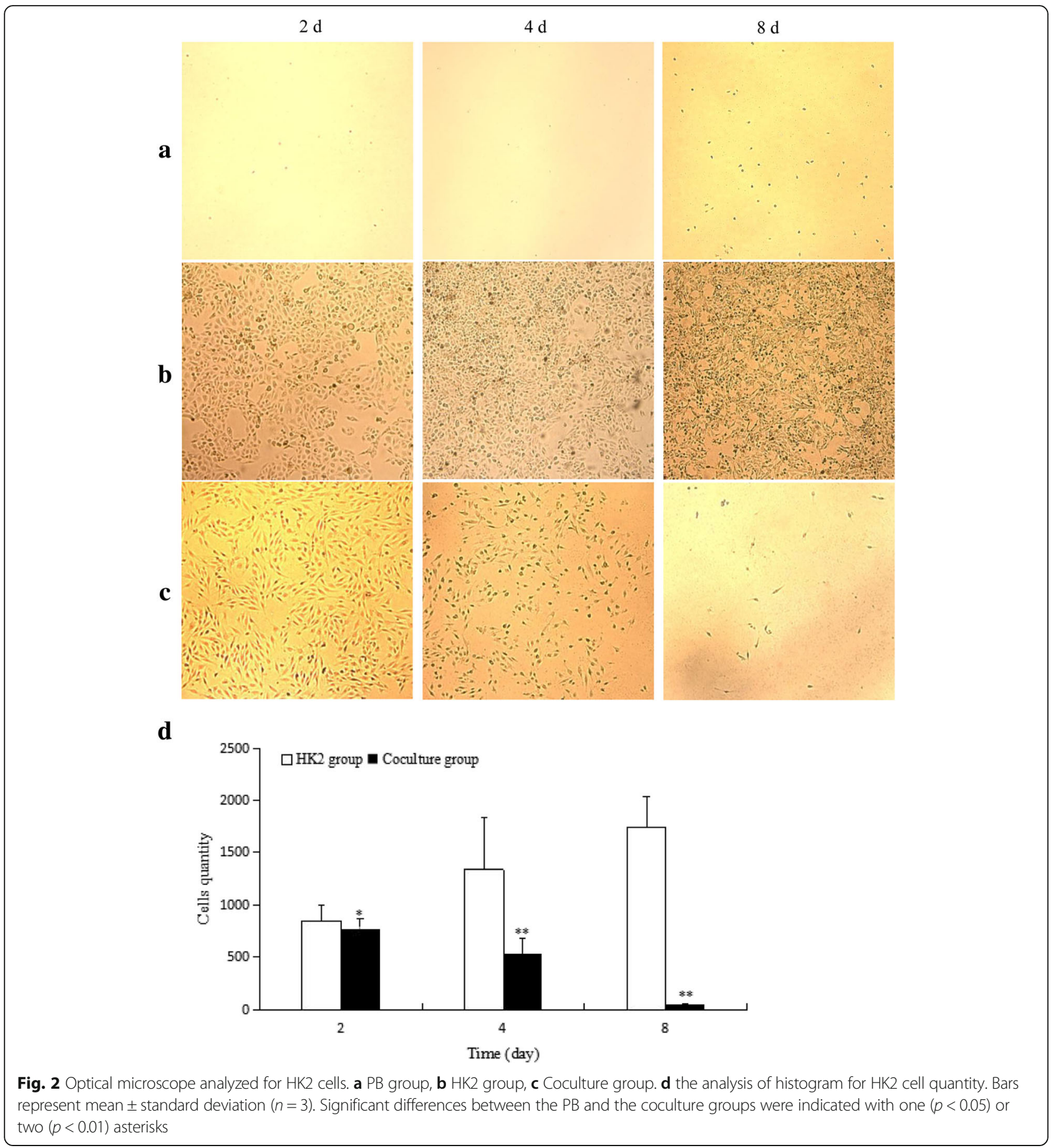

Detection of the concentration of blood group antibody, IgG and IgM

Based on these results, the concentration of blood group $\mathrm{B}$ antibody, IgG and IgM in supernate was analyzed by immunoturbidimetry assay. As Fig. 5 showed, blood group B antibody was significantly increased to 2.35 fold at day 4 (Fig. 5a), IgG was significantly increased to 3.60 and 2.81 folds at days 4 and 8 respectively (Fig. 5b), and
IgM had no significant change between PB and coculture groups (Fig. 5c).

\section{Discussion}

$\mathrm{ABOi}-\mathrm{KT}$ is an effective and important strategy to resolve the problem of kidney shortage [16-21], and the allograft in a small cohort of recipients aided survival 
$\mathbf{a}$

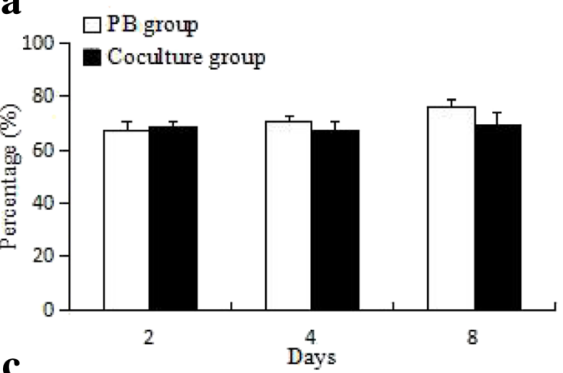

c

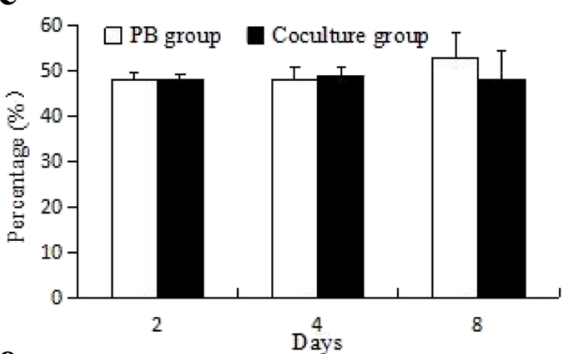

$\mathbf{e}$

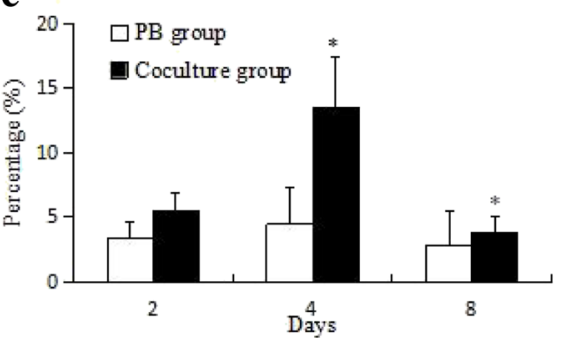

b
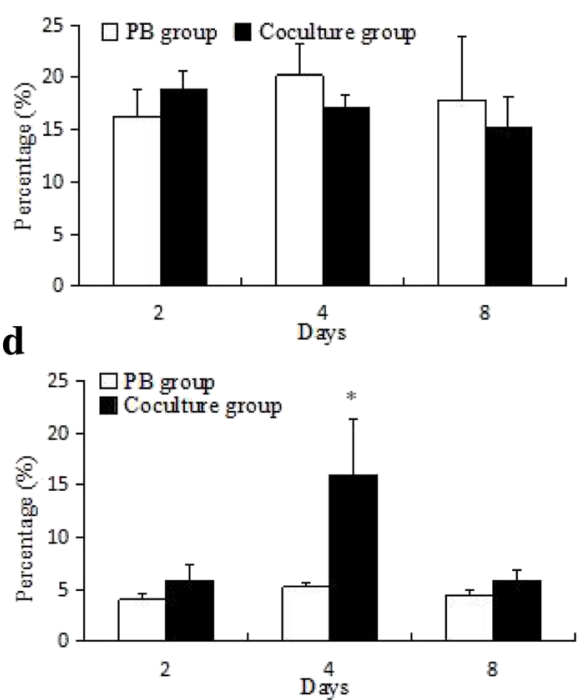

f

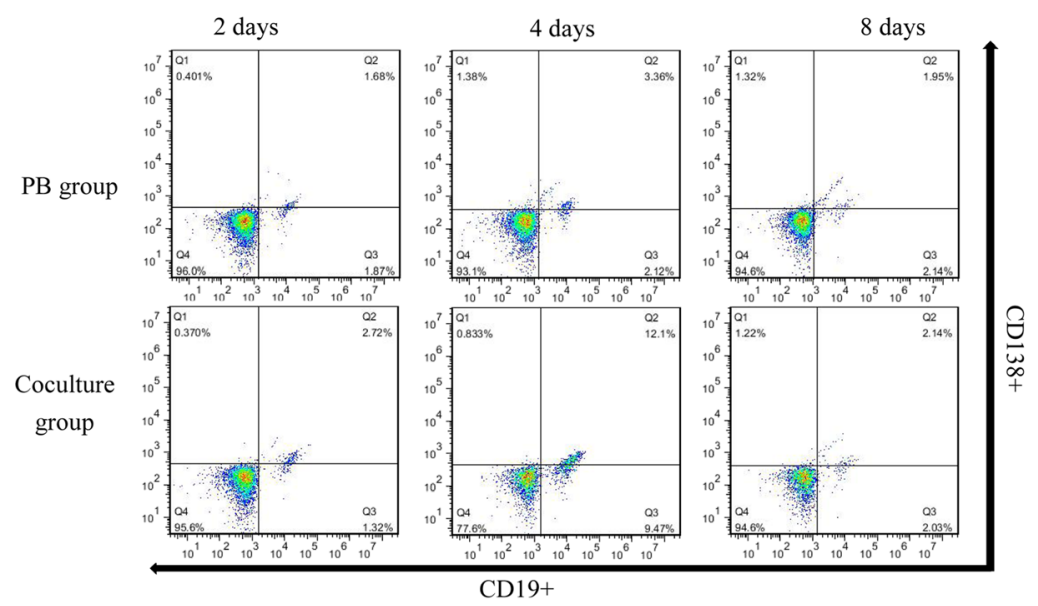

Fig. 3 The T cells and B cells subsets analyzed by flow cytometry. a $C D 3^{+}$phenotype $T$ cells, b $C D 3^{+} C D 8^{+}$phenotype $T$ cells, $\mathbf{c} C D 3^{+} C D 4^{+}$phenotype T cells, $\mathbf{d}$ CD $19^{+}$phenotype B cells, e CD138 $8^{+}$phenotype B cells. $\mathbf{f}$ The flow cytometry scatter plot of $C D 19^{+}$and $C D 138^{+}$phenotype B cells. Bars represent mean \pm standard deviation $(n=3)$. Significant differences between the PB and the coculture groups were indicated with one $(p<0.05)$ asterisks

because of immune tolerance mediated by B cells activation [22, 23]. In this study, HK2 was verified to express blood group B antigen (Fig. 1) when cocultured with lymphocyte of blood group A.

Optical microscope observation shown that the proliferative activity of $\mathrm{HK} 2$ cells in coculture group decreased and a small number of HK2 cells survived by day 8 (Fig. 2c, d). This phenomenon may be related to humoral immunity mediated by B cells or cell immunity mediated by $\mathrm{T}$ cells [24-26].

In immunoreactions mediated by lymphocytes, CD3 ${ }^{+} \mathrm{CD}^{+}$and $\mathrm{CD}^{+} \mathrm{CD}^{+} \mathrm{T}$ cells play an important role 


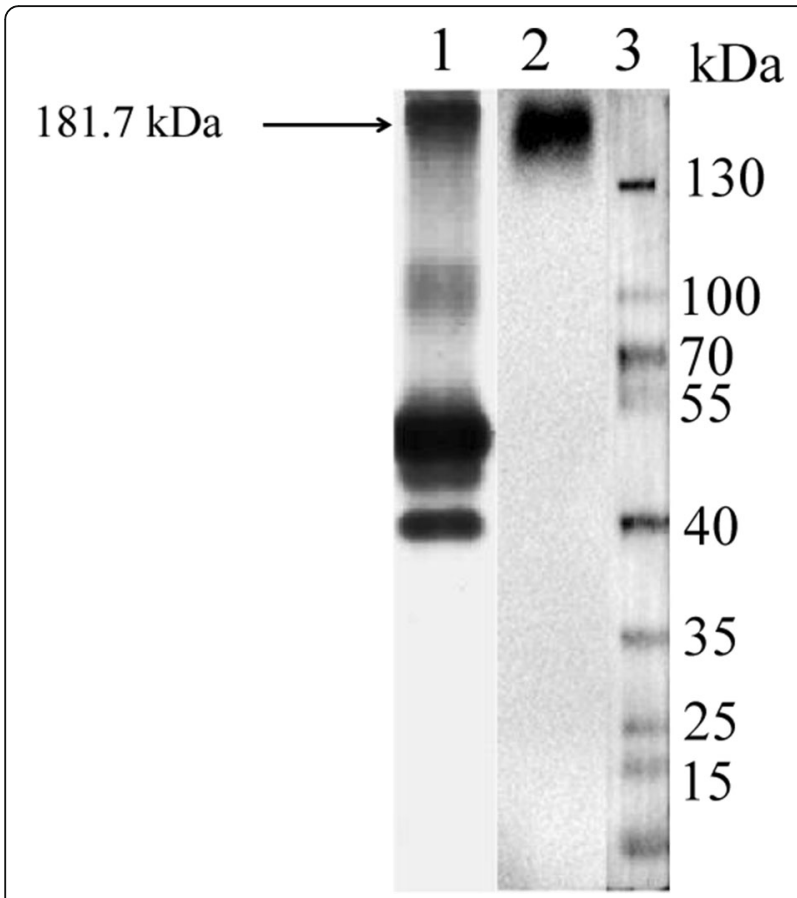

Fig. 4 The analysis of western-blotting for mouse monoclonal to anti-blood group B antibody in reagent. Lane 1. PAGE assay, lane 2. Western-blotting assay, lane 3. protein mark

as helper $\mathrm{T}$ cells [27] and cytotoxic $\mathrm{T}$ cells [28]. The $\mathrm{CD}^{+} \mathrm{CD}^{+} \mathrm{T}$ cells, especially $\mathrm{T}$ follicular helper ( $\mathrm{Tfh}$ ) cells, secrete interleukin-21 [29] and express CD40 ligands and other inducible costimulator such as CD137 [30] on their surface [31], to promote B cells $\left(\mathrm{CD} 19^{+}\right)$class-switch and their differentiation into plasma cells $\left(\mathrm{CD} 138^{+}\right)$after antigen challenge [32-34] (Fig. 6) [35]. Thus, the $\mathrm{T}$ cells $\left(\mathrm{CD}^{+}, \mathrm{CD}^{+}{ }^{+} \mathrm{CD} 4^{+}\right.$and $\left.\mathrm{CD}^{+} \mathrm{CD}^{+}\right)$and $\mathrm{B}$ cells $\left(\mathrm{CD} 19^{+}\right.$and $\left.\mathrm{CD} 138^{+}\right)$subset were analyzed by flow cytometry. As a result, after stimulation with HK2, the T cells phenotype had no significant variation (Fig. $3 \mathrm{a}-\mathrm{c}$ ), $\mathrm{CD} 19^{+} \mathrm{B}$ cells (Fig. 3d, f) were significantly increased to 3.07 fold at day 4 , and

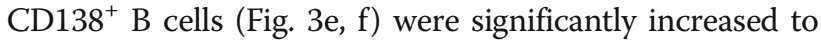
3.02 and 1.36 folds at days 4 and 8 respectively. Conjecturally, the B cells activation was induced by HK2, and it may be an important factor for the decrease of HK2 cells proliferative activity.

In addition, for further quantitative analysis the variation of blood group B antibody concentration, the mouse monoclonal to anti-blood group $\mathrm{B}$ antibody in reagent was detected as Eppler A et al. [36] and Yawata $\mathrm{K}$ et al. [37] reported with some modification. As a result, the protein with a molecular weight about $181.7 \mathrm{kDa}$ was identified as mouse anti-human blood group B antibody with concentration $0.57 \mathrm{mg} / \mathrm{ml}$ in the reagent (Fig. 4 and Additional file 1: Figure S1).

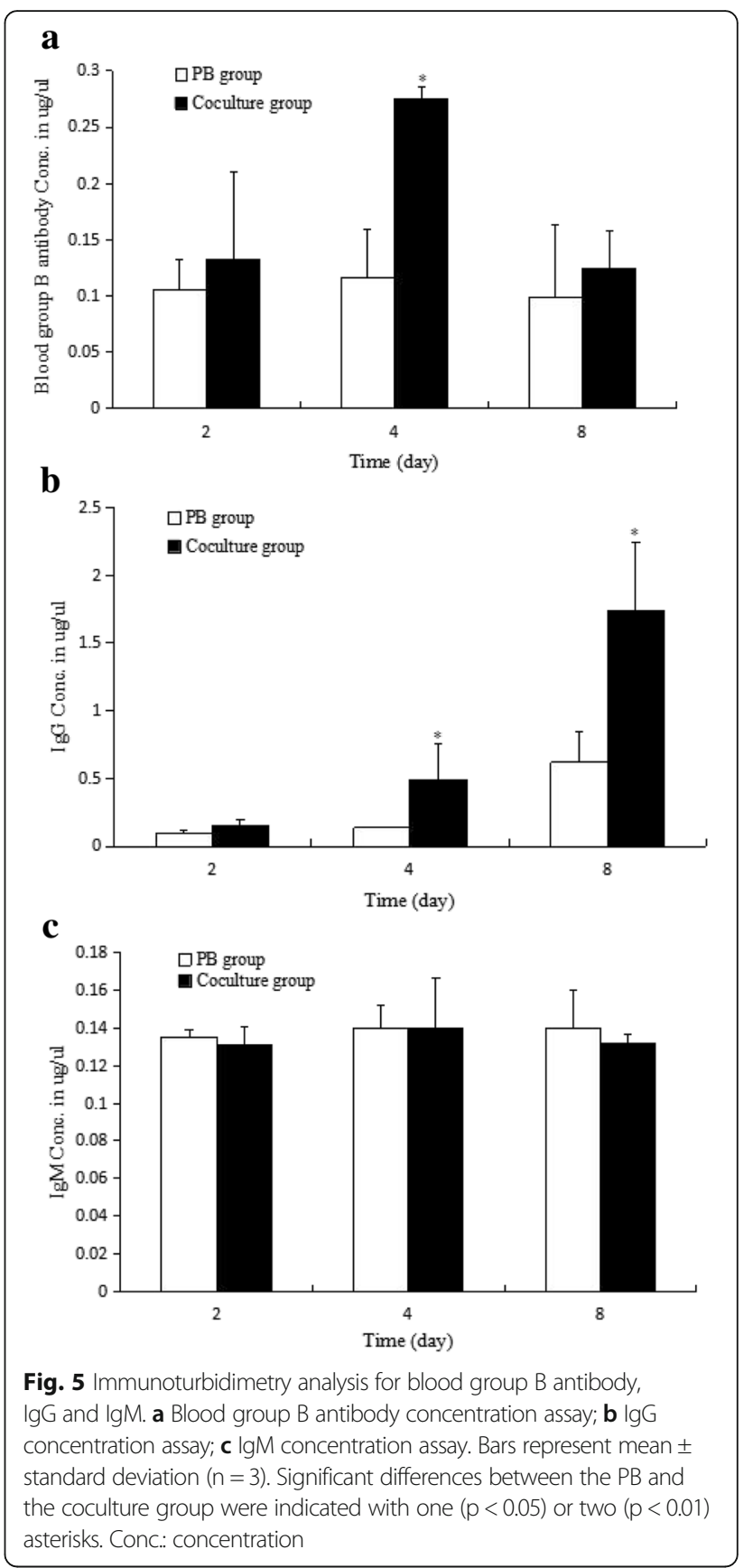

Based on these results, the blood group antibody in the supernate was analyzed by immunoturbidimetry. The results showed that blood group B antibody was significantly increased to 2.35 fold at day 4 (Fig. 5a), IgG was significantly increased to 3.60 and 2.81 fold at days 4,8 (Fig. 5b), and IgM has no significant change at the detective point (Fig. 5c). This was similar to the report that immunogloblulin was class switched to IgG4 in warthin tumor and the serum IgG4 levels were increased [7]. Consequently, it is suggested the B cells were activated by HK2 cells 


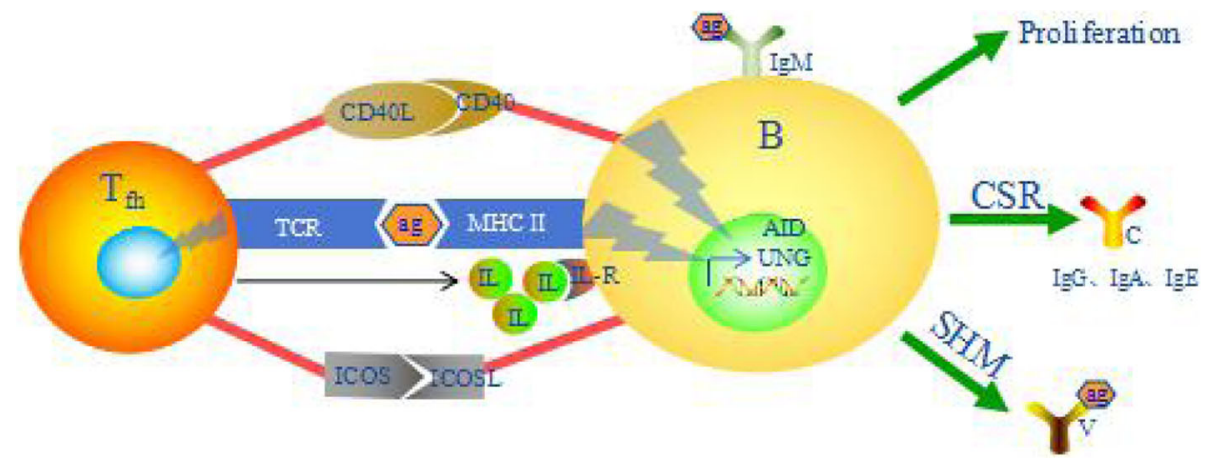

Fig. 6 The activation of T follicular helper cells for B cells*. Tfh: T follicular helper, TCR: T cell receptor, MHC II: major histocompatibility complex class II, ICOS: Inducible costimulator, ICOSL: ICOS ligand, CD40L: CD40 ligand, IL: interleukin, IL-R: interleukin receptor, CSR: class switch recombination, SHM: somatic hypermutation, AID: activation-induced cytidine deaminase, UNG: uracil-N-glycosylase. ${ }^{*}$ The figure was drawn as Durandy er al [35] reported with some modification

expressing blood group B antigen and blood group B antibodies played a key role in HK2 cells apoptosis.

\section{Conclusions}

Our researches demostrated that the B cells were activated and induced differentiation to plasmocytes secreted blood group B antibody after HK2 cells treatment. This will be beneficial for further exploration of the mechanism of $\mathrm{B}$ cells activation after ABOi HK2 cells stimulation.

\section{Additional file}

Additional file 1: Figure S1. the establishment of protein-gray value curve of BSA. (A) PAGE assay for different concentration of BSA, lane 1. $0.5 \mu \mathrm{g} B S A$, lane $2.1 \mu \mathrm{g} \mathrm{BSA}$, lane 3. $2 \mu \mathrm{g} \mathrm{BSA}$, lane $4.4 \mu \mathrm{g} B S A$, lane 5 . $8 \mu \mathrm{g} \mathrm{BSA}$; $(B)$ the relationship analysis of BSA gray value and protein. Bars represent mean \pm standard deviation $(n=3)$. (PDF $611 \mathrm{~kb})$

\section{Abbreviations}

ABOi-KT: ABO blood group system incompatible kidney transplantation: AID: Activation-induced cytidine deaminase; BSA: Bovine serum albumin; CD40L: CD40 ligand; Conc:: Concentration; CSR: Class switch recombination; FCS: Fetal calf serum; ICOS: Inducible costimulator; ICOSL: ICOS ligand; Ig: Immunoglobulin; IL: Interleukin; IL-R: Interleukin receptor; KLH: Keyhole limpet hemocyanin; MHC II: Major histocompatibility complex class II; PAGE: Polyacrylamide gel electrophoresis; PBS: Phosphate buffer solution; PVDF: Polyvinylidene fluoride; S.D.: Standard deviation; SHM: Somatic hypermutation; TBS: Tris buffer solution; TCR: T cell receptor; $T_{\text {fh: }}: T$ follicular helper; TTBS: Tween tris buffer solution; UNG: uracil-N-glycosylase

\section{Acknowledgments}

Not applicable.

\section{Funding}

This work was supported by the Zhengxiang scholar program of the University of South China.

\section{Availability of data and materials}

All data in the article can be requested from the corresponding author.

\section{Authors' contributions}

Laboratory experiments, data analysis and manuscript writing were accomplished by JSC; experimental design, date analysis and manuscript revise were accomplished by LGL; manuscript revise and date analysis were accomplished by YSZ; the guidance of experimental design and manuscript writing was accomplished by JHX and $\mathrm{YW}$. All authors have read and approved the final manuscript.

Ethics approval and consent to participate

Written consent was obtained from the participants. The experiments were approved by the Animal Welfare and Research Ethics Committee of the Institute of University of South China.

\section{Consent for publication \\ Not applicable.}

\section{Competing interests}

The authors declare that they have no competing interest.

\section{Publisher's Note}

Springer Nature remains neutral with regard to jurisdictional claims in published maps and institutional affiliations.

\section{Author details}

${ }^{1}$ Institute of Pathogenic Biology, Medical College, Hunan Provincial Key Laboratory for Special Pathogens Prevention and Control; Hunan Province Cooperative Innovation Center for Molecular Target New Drug Study, University of South China, Hengyang, Hunan 421001, China. ${ }^{2}$ Clinical research center, Institute of Pathogenic Biology, Medical College, The Second Affiliated Hospital, University of South China, Hengyang, Hunan 421001, China. ${ }^{3}$ Urinary surgery, The Second Affiliated Hospital, University of South China, Hengyang, Hunan 421001, China.

Received: 29 March 2017 Accepted: 6 December 2017

Published online: 16 December 2017

\section{References}

1. Uchida J, Kuwabara N, Machida Y, Iwai T, Naganuma T, Kumada N, et al. Excellent outcomes of ABO-incompatible kidney transplantation: a singlecenter experience. Transplant Proc. 2012;44(1):204-9.

2. Park WY, Kang SS, Park SB, Park UJ, Kim HT, Cho WH, et al. Comparison of clinical outcomes between $\mathrm{ABO}$-compatible and ABO-incompatible spousal donor kidney transplantation. Kidney Res Clin Pract. 2016;35(1):50-4.

3. Yu JH, Chung BH, Yang CW. Impact of ABO incompatible kidney transplantation on living donor transplantation. PLoS One. 2017;12(3): e0173878.

4 Subramanian V, Gunasekaran M, Gaut JP, Phelan D, Vachharajani N, Santos $\mathrm{RD}$, et al. Mohanakumar, $\mathrm{ABO}$ incompatible renal transplants and decreased likelihood for developing immune responses to HLA and kidney selfantigens. Hum Immunol. 2016;77(1):76-83. 
5. Ferrari P, Hughes PD, Cohney SJ, Woodroffe C, Fidler S, D'Orsogna L. ABOincompatible matching significantly enhances transplant rates in kidney paired donation. Transplantation. 2013;96(9):821-6.

6. Makroo RN, Nayak S, Chowdhry M, Jasuja S, Sagar G, Rosamma NL, et al. Role of therapeutic plasma exchange in reducing $A B O$ titers in patients undergoing ABO-incompatible renal transplant. Apollo medicine. 2016;31(1):31-6.

7. Aga M, Kondo S, Yamada K, Wakisaka N, Yagi-Nakanishi S, Tsuji A, et al. Immunoglobulin class switching to lgG4 in Warthin tumor and analysis of serum lgG4 levels and IgG4-positive plasma cells in the tumor. Hum Pathol. 2014;45(4):793-801.

8. Kracker S, Gardes P, Mazerolles F, Durandy A. Immunoglobulin class switch recombination deficiencies. Clin Immunol. 2010;135(2):193-203.

9. Urschel S, Ryan LA, Larsen IM, Derkatz K, Rebeyka IM, Ross DB, et al. C3d plasma levels and CD21 expressing B-cells in children after ABOincompatible heart transplantation: alterations associated with blood group tolerance. J Heart Lung Transplant. 2014;33(11):1149-56.

10. Chesneau M, Pallier A, Braza F, Lacombe G, Le Gallou S, Baron D, et al. Unique B cell differentiation profile in tolerant kidney transplant patients. Am J Transplant. 2014;14(1):144-55.

11. Urschel S, Ryan LA. M Larsen I, Biffis K, Dijke IE, west LJ. Development of Bcell memory in early childhood and the impact on antigen-specific tolerance after heart transplantation, J. Heart lung transplant. J Heart Lung Transplant. 2016;35(4):491-9.

12. Batista FD, Harwood NE. The who, how and where of antigen presentation to B cells. Nat Rev Immunol. 2009:9(1):15-27.

13. Methot SP, Di Noia JM. Molecular mechanisms of somatic hypermutation and class switch recombination. Adv Immunol. 2017;133:37-87.

14. Cao J, Chen C, Wang Y, Chen X, Chen Z, Luo X. Influences of autologous dendritic cells on cytokine-induced killer cells proliferation, cell phenotype and anti-tumor activity in vitro. Oncol Lett. 2016;12(3):2033-7.

15. Kounelis S, Kapranos N, Kouri E, Coppola D, Papadaki H, Jones MW. Immunohistochemical profile of endometrial adenocarcinoma: a study of 61 cases and review of the literature. Mod Pathol. 2000;13(4):379-88.

16. Bentall A, R Barnett AN, Braitch M, Kessaris N, McKane W, Newstead C, et al. Clinical outcomes with $\mathrm{ABO}$ antibody titer variability in a multicenter study of $\mathrm{ABO}$-incompatible kidney transplantation in the United Kingdom. Transfusion. 2016;56(11):2668-79.

17. Fadeyi EA, Stratta RJ, Farney AC, Pomper GJ. Successful ABO-incompatible renal transplantation: blood group $A 1 B$ donor into $A 2 B$ recipient with antiA1 isoagglutinins. Am J Clin Pathol. 2016;146(2):268-71.

18. Koo TY, Yang J. Current progress in ABO-incompatible kidney transplantation. Kidney Res Clin Pract. 2015;34(3):170-9.

19. Shin M, Kim SJ. ABO incompatible kidney transplantation-current status and uncertainties. J Transp Secur. 2011;2011:970421.

20. Tanabe T, Ishida H, Horita S, Yamaguchi Y, Toma H, Tanabe K. Decrease of blood type antigenicity over the long-term after ABO-incompatible kidney transplantation. Transpl Immunol. 2011;25(1):1-6.

21. Abboud I, Peraldi MN, Glotz D. Renal transplantation from $A B O$ incompatible donors. J Med Liban. 2015;63(3):159-63.

22. van de Veen W, Stanic B, OF W, Jansen K, Globinska A, Akdis M. Role of regulatory $B$ cells in immune tolerance to allergens and beyond. J Allergy Clin Immunol. 2016;138(3):654-65.

23. Perera J, Zheng Z, Li S, Gudjonson H, Kalinina O, Benichou JI, et al. Selfantigen-driven thymic $B$ cell class switching promotes $T$ cell central tolerance. Cell Rep. 2016;17(2):387-98.

24. Chen C, Li J, Bi Y, Yang L, Meng S, Zhou Y, et al. Synthetic B- and T-cell epitope peptides of porcine reproductive and respiratory syndrome virus with Gp96 as adjuvant induced humoral and cell-mediated immunity. Vaccine. 2013;31(14):1838-47.

25. Montgomery RA, Cozzi E, West LJ, Warren DS. Humoral immunity and antibody-mediated rejection in solid organ transplantation. Semin Immunol. 2011:23(4):224-34

26. Chang MC, Chiang CP, Lin CL, Lee JJ, Hahn LJ, Jeng JH. Cell-mediated immunity and head and neck cancer: with special emphasis on betel quid chewing habit. Oral Oncol. 2005;41(8):757-75.

27. Chen J, Wei Y, He J, Cui G, Zhu Y, Lu C, et al. Natural killer T cells play a necessary role in modulating of immune-mediated liver injury by gut microbiota. Sci Rep. 2014;4:7259.

28. Salaun B, Yamamoto T, Badran B, Tsunetsugu-Yokota Y, Roux A, Baitsch L, et al. Differentiation associated regulation of microRNA expression in vivo in human CD8+ T cell subsets. J Transl Med. 2011;9:44.
29. Bentebibel SE, Schmitt N, Banchereau J, Ueno H. Human tonsil B-cel lymphoma 6 (BCL6)-expressing CD4+ T-cell subset specialized for B-cell help outside germinal centers. Proc Natl Acad Sci U S A. 2011;108(33):E488-97.

30. Alfaro C, Echeveste Jl, Rodriguez-Ruiz ME, Solorzano JL, Perez-Gracia JL, Idoate MA, et al. Functional expression of CD137 (4-1BB) on Thelper follicular cells. Oncoimmunology. 2015:4(12):e1054597.

31. Banchereau J, Bazan F, Blanchard D, Brière F, Galizzi JP, van Kooten C, et al. The CD40 antigen and its ligand. Annu Rev Immunol. 1994;12:881-922.

32. Schmitt N, Bentebibel SE, Ueno H. Phenotype and functions of memory Tfh cells in human blood. Trends Immunol. 2014;35(9):436-42.

33. Spolski R, Leonard WJ. Interleukin-21: basic biology and implications for cancer and autoimmunity. Annu Rev Immunol. 2008;26:57-79.

34. MacLennan IC, Toellner KM, Cunningham AF, Serre K, Sze DM, Zúñiga E, et al. Extrafollicular antibody responses. Immunol Rev. 2003;194:8-18.

35. Durandy A, Kracker S. Immunoglobulin class switch recombination deficiencies. Arthritis Res Ther. 2012;14(4):218.

36. Eppler A, Weigandt M, Schulze S, Hanefeld A, Bunjes H. Comparison of different protein concentration techniques within preformulation development. Int J Pharm. 2011;421(1):120-9.

37. Yawata K, Osada S, Tanahashi T, Matsui S, Sasaki Y, Tanaka Y, et al. The significant role of cyclin D1 in the synergistic growth-inhibitory effect of combined therapy of vandetanib with 5-fluorouracil for gastric cancer. Anticancer Res. 2016;36(10):5215-26.

\section{Submit your next manuscript to BioMed Central and we will help you at every step:}

- We accept pre-submission inquiries

- Our selector tool helps you to find the most relevant journal

- We provide round the clock customer support

- Convenient online submission

- Thorough peer review

- Inclusion in PubMed and all major indexing services

- Maximum visibility for your research

Submit your manuscript at www.biomedcentral.com/submit
) Biomed Central 